\title{
Tracheal Compression by Aberrant Brachiocephalic Trunk Accompanying Variant Origin of the Vertebral Artery
}

\author{
Compresión Traqueal por un Tronco Braquiocefálico Aberrante Acompañado \\ de una Variación en el Origen de la Arteria Vertebral
}

Kiwook Yang'; Jae-Hee Park¹; Yong-Suk Moon²; Hong-Tae Kim² \& Jae-Ho Lee

YANG, K.; PARK, J. H.; MOON, Y. S.; KIM H. T. \& LEE, J. H. Tracheal compression by aberrant brachiocephalic trunk accompanying Variant origin of the vertebral artery. Int. J. Morphol., 35(2):469-471, 2017.

SUMMARY: The aorta is the main arterial trunk in the human body, however, its variation was extremely variable. During an educational dissection, aberrant branching pattern of aortic arch was found in a Korean cadaver. The brachiocephalic trunk (innominate artery) originated from the aortic arch at the left side of the trachea. It crossed the trachea and divided into the right common carotid and subclavian arteries. The left vertebral artery originated from the aortic arch between the origins of the left common carotid artery and the left subclavian artery, then the left vertebral artery coursed upward to the transverse foramen of the C7. The author describes this previously novel case report with aberrant brachiocephalic trunk and left vertebral arteries and discusses the clinical implications of such a variant.

KEY WORDS: Aberrant brachiocephalic trunk; Aortic arch; Tracheal compression; Variation; Vertebral artery.

\section{INTRODUCTION}

The aortic arch, located in the superior mediastinum, gives rise to three classical branches, namely the brachiocephalic trunk (BT), the left common carotid artery (LCCA) and the left subclavian artery (LSA). Because there is no brachiocephalic artery for the left side, LCCA and LSA come directly from the aortic arch. The vertebral artery (VA) arises from the superior surface of the first part of the subclavian artery medial to the scalenus anterior muscle.

Variations in the aortic arch branches have previously been investigated by many authors (Gluncic et al., 1999; Cag ${ }^{-}$li et al., 2005). This frequent variation in aortic arch can occur due to altered development of primitive aortic arch of the embryo during the early gestation period. Increasing activity of cardiovascular intervention requires deeper understanding in the anatomy of the aortic arch (Mahmutyazicioglu et al., 1998; Natsis et al., 2009; Vucurevic et al., 2012). Therefore, many studies about the branch of aortic arch were performed by radiological approaches, however, there was few reports about this variation in Korean cadaver (Shin et al., 2008).

In this article, we report variant origins of $\mathrm{BT}$ and
VA and discuss the clinical significance of this variation. And the origin of BT was also analyzed in 30 cadavers to clarify its morphology. This knowledge may help clinicians in performing invasive procedures and surgery.

\section{CASE REPORT}

During a routine dissection of the branches of the aortic arch of a 73-year-old female cadaver at the School of Medicine, Keimyung University, unique variation of aortic arch was found. The cadaver was formalin-fixed. The anterior neck and thoracic cavity was opened after removal of the skin, superficial fascia, deep fascia, and muscles. Both lungs were removed, then, the superior vena cava and brachiocephalic veins were confirmed. And the pericardium was opened to expose the aortic arch. Fatty tissue and other tissues were also removed to clarify the branches of the aortic arch and variations in branching pattern observed.

Aortic arch begun at the level of the upper margin of the second sternocostal articulation of the right side, and

\footnotetext{
${ }^{1}$ Department of Anatomy, Keimyung University School of Medicine, Daegu, Republic of Korea.

${ }^{2}$ Department of Anatomy, School of Medicine, Catholic University, Daegu, Republic of Korea.
} 
run upward to cross the trachea on the left side of the fourth thoracic vertebral level. And then, it gave off four branches, BT, LCCA, left VA (LVA), and LSA (Fig. 1). BT was originated from $13.1 \mathrm{~mm}$ left of the mid-vertebral line, and then, it crossed the trachea and continued $43 \mathrm{~mm}$ more. Finally, it divided into RCCA and RSA. LCCA, LVA, and LSA were

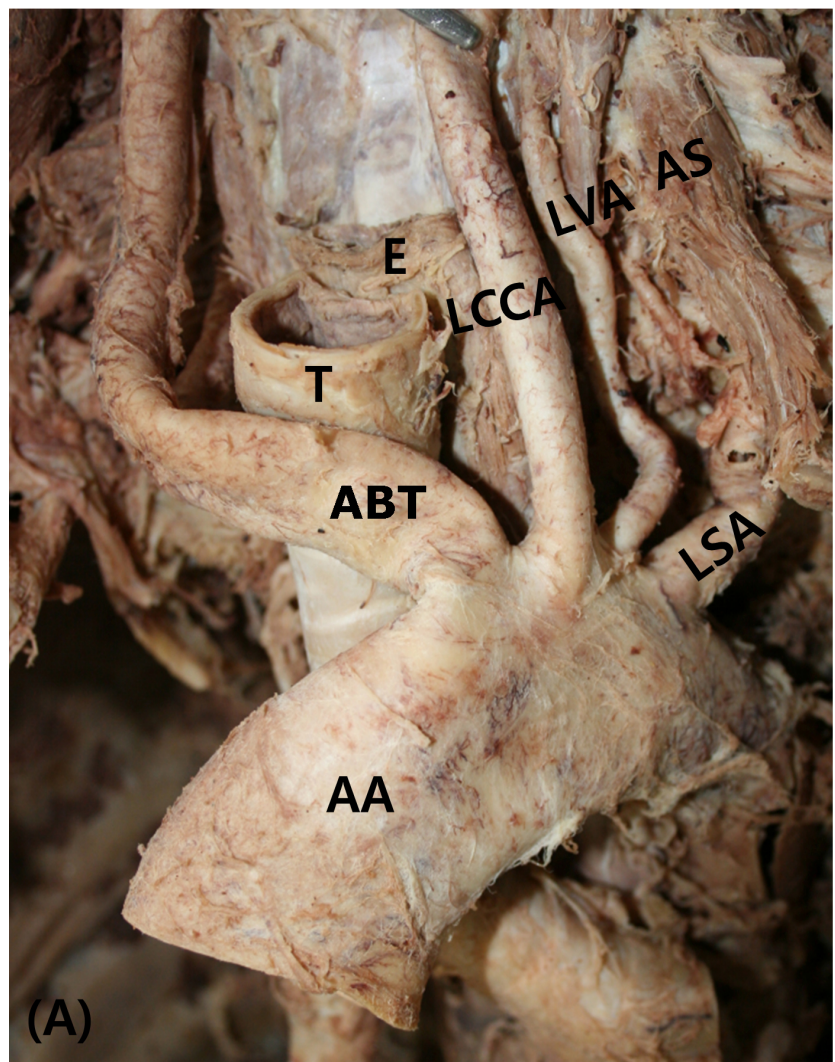

originated sequentially next to BT. LCCA and LSA showed normal course. LSA run upward and passed between anterior and middle scalene muscles. LVA continued upward and entered deep to the transverse process at the level of the 7th cervical vertebrae. We cannot find any vascular disease and clue for haemodynamic change in cadaver.

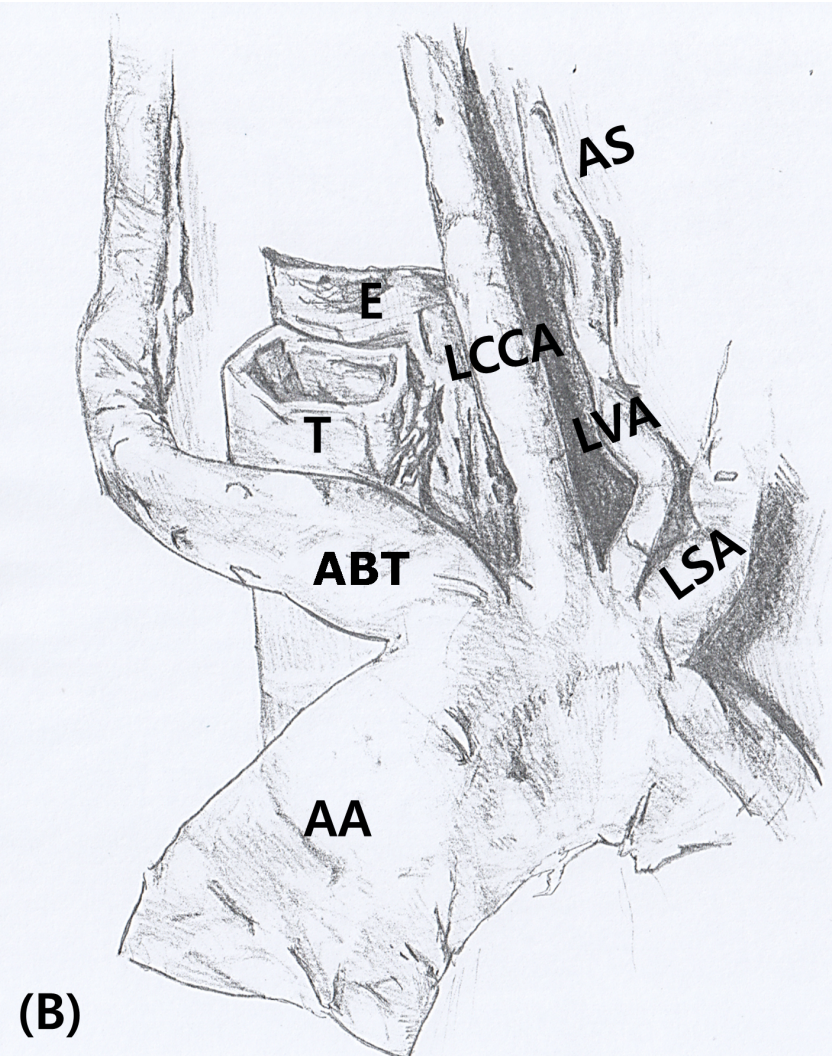

Fig. 1. Photograph (A) and schematic drawing (B) of the variation in the aortic arch. An aberrant brachiocephalic trunk (ABT) originated from the aortic arch (AA) at the left side of the trachea (T). The left vertebral artery (LVA) originated from the aortic arch between the origins of the left common carotid artery (LCCA) and the left subclavian artery (LSA). AS, anterior scalene muscle; E, esophagus.

\section{DISCUSSION}

The aortic arch generally gives three branches, as BT, LCCA, and LSA. Variations of BT were frequently reported and its clinical significances were also suggested (Mahmutyazicioglu et al.; Gluncic et al.; Cagli et al.; Natsis et al.; Vucurevic et al.). Though the official name for BT is the brachiocephalic trunk from Nomina Anatomica 1998, its variation and pathologic condition still continues to refer as aberrant BT (ABT) and BT compression syndrome (BTCS), respectively (Padget, 1948). Present report showed an aortic arch gave off left-shifted ABT and LVA. This normal arrangement of the aortic arch was shown in about 60$70 \%$ of cadavers by many authors (Natsis et al.; Vucurevic et al.). Frequently reported variants were LCCA originating from the $\mathrm{BT}$, right common carotid artery and right subclavian artery originating individually from the aortic arch. Additionally, the left brachiocephalic trunk (Double brachiocephalic trunk) gave off LCCA and LSA. The left vertebral artery (LVA) may also arise from aortic arch, between the LCCA and LSA. Previous studies demonstrated that the origin of the LVA was extremely various such as from the thyrocervical trunk, BT, the common carotid artery, the external carotid artery, and a common carotid trunk for LSA and LVA (Nonami et al., 1998).

However, left-shifted ABT was rare, moreover, it has a significant and clinical implication by crossing the trachea (Berdon et al., 1969; Strife, et al., 1981). Previous study showed that BT originated from the mid-vertebrae line with a right side deviation of an average of $0.92 \mathrm{~mm}$ (right 19.2 $\mathrm{mm}$ - left $11.8 \mathrm{~mm}$ ), almost in the mid-vertebrae area (Shin et al.). The origins of LCCA and the LSA were deviated to 
the left by an average of $12.3 \mathrm{~mm}$ and an average of 22.8 $\mathrm{mm}$, respectively. In present report, the origin of $\mathrm{ABT}$ was $13.1 \mathrm{~mm}$ left to the mid-vertebral line and similar case report demonstrated a $22 \mathrm{~mm}$ left-deviated ABT. Moreover, LVA originated directly from the aortic arch in our case. These combined variations have not been reported anywhere and have clinical and embryological significances.

To contribute to knowledge of BT variation, we measured the origin of BT in 30 Korean cadavers. The BT originates from the mid-vertebral line with a right side deviation of an average of $1.23 \pm 5.6 \mathrm{~mm}$. This varied from right $17.5 \mathrm{~mm}$ to left $13.1 \mathrm{~mm}$ and this deviation was more distal than that in previous study $(11.8 \mathrm{~mm})$ (Shin et al.). Therefore, our case was extremely deviated ABT case with LVA variation. This anomalous branching pattern of the aortic arch can alter the cerebral haemodynamics, which in turn can lead to cerebral abnormalities (Nonami et al.). To avoid iatrogenic injury, clinicians and surgeons should be aware of aortic arch variations.

In the present report, we showed a right deviated BT crossing the trachea with a variation in the VA. The knowledge of development of anomalous LVA is well known, especially, in cases of LVA originating between LCCA and LSA (Gluncic et al.). Briefly, this variation may be due to the persistence of the left $6^{\text {th }}$ inter-segmental instead of left $7^{\text {th }}$ inter-segmental artery as the first part of vertebral artery. However, left-deviation of BT has not been reported frequently, therefore, there was no embryological hypothesis for this variation. Further study should be required to clarify the development of these variations.

ACKNOWLEDGEMENTS. This study was supported by grants of the Basic Science Research Program through the National Research Foundation of Korea (NRF) funded by the Ministry of Education (NRF-2014R1A6A3A04058057) and by the Korean Government (MSIP; No. 2014R1A5A2010008).

YANG, K.; PARK, J. H.; MOON, Y. S.; KIM H. T. \& LEE, J. H. Compresión Traqueal por un tronco braquiocefálico aberrante acompañado de una variación en el origen de la arteria vertebral. Int. J. Morphol., 35(2):469-471, 2017.

RESUMEN: La aorta es el tronco arterial principal del cuerpo humano, sin embargo, su variación es extremadamente variable. Durante una disección de rutina de un cadáver coreano, se encontró un patrón de ramificación aberrante del arco aórtico. El tronco braquiocefálico se originaba del arco aórtico en el lado izquierdo de la tráquea. Cruzaba la tráquea y se dividía en las arterias carótida común y subclavia derecha. La arteria vertebral izquierda se originó a partir del arco aórtico entre los orígenes de la arteria carótida co- mún izquierda y la arteria subclavia izquierda, luego la arteria vertebral izquierda ascendió hacia el foramen transversal de la séptima vértebra cervical. Se describe un caso de tronco braquiocefálico aberrante y la correspondiente arteria vertebral izquierda y se discuten las implicaciones clínicas de tal variante.

PALABRAS CLAVE: Tronco braquiocefálico aberrante; Arco aórtico; Compresión traqueal; Variación; Arteria vertebral.

\section{REFERENCES}

Berdon, W. E.; Baker, D. H.; Bordiuk, J. \& Mellins, R. Innominate artery compression of the trachea in infants with stridor and apnea. Radiology, 92(2):272-8, 1969.

Cag ${ }$ li, K.; Yildiz, U.; Ergün, K.; Emir, M. \& Birincioglu, C. L. Aberrant patent ductus arteriosus associated with double brachiocephalic trunk and interrupted left subclavian artery. Int. J. Cardiol., 101(3):509-11, 2005.

Gluncic, V.; Ivkic, G.; Marin, D. \& Percac, S. Anomalous origin of both vertebral arteries. Clin. Anat., 12(4):281-4, 1999.

Mahmutyazicioglu, K.; Saraç, K.; Bölük, A. \& Kutlu, R. Duplicate origin of left vertebral artery with thrombosis at the origin: color Doppler sonography and CT angiography findings. J. Clin. Ultrasound, 26(6):323$5,1998$.

Natsis, K. I.; Tsitouridis, I. A.; Didagelos, M. V.; Fillipidis, A. A.; Vlasis, K. G. \& Tsikaras, P. D. Anatomical variations in the branches of the human aortic arch in 633 angiographies: clinical significance and literature review. Surg. Radiol. Anat., 31(5):319-23, 2009.

Nonami, Y.; Tomosawa, N.; Nishida, K. \& Nawata, S. Dissecting aortic aneurysm involving an anomalous right subclavian artery and isolated left vertebral artery: case report and review of the literature. J. Cardiovasc. Surg. (Torino), 39(6):743-6, 1998.

Padget, D. H. The development of the cranial arteries in the human embryo. Contribution to embryology. Carnegie Inst., 32:205-61, 1948.

Shin, I. Y.; Chung, Y. G.; Shin, W. H.; Im, S. B.; Hwang, S. C. \& Kim, B. T. A morphometric study on cadaveric aortic arch and its major branches in 25 korean adults : the perspective of endovascular surgery. J. Korean Neurosurg. Soc., 44(2):78-83, 2008.

Strife, J. L.; Baumel, A. S. \& Dunbar, J. S. Tracheal compression by the innominate artery in infancy and childhood. Radiology, 139(1):73-5, 1981.

Vucurevic, G.; Marinkovic, S.; Puskas, L.; Kovacevic, I.; Tanaskovic, S.; Radak, D. \& Ilic, A. Anatomy and radiology of the variations of aortic arch branches in 1,266 patients. Folia. Morphol. (Warsz.), 72(2):113-22, 2012 .

\author{
Corresponding author: \\ Jae-Ho Lee \\ Department of Anatomy \\ Keimyung University School of Medicine, 2800 \\ Dalgubeoldaero, Dalseo-Gu, \\ Daegu \\ Republic of Korea.
}

E-mail: anato82@dsmc.or.kr

Received: 17-01-2017

Accepted: 20-03-2017 